\title{
Kara Midye'lerin (Mytilus galloprovincialis) Gram-Negatif Bakteri Florasının Tespiti
}

\author{
Figen Esin KAYHAN*, Nüzhet Cenk SESAL, Salim GÜLDÜR \\ Marmara Üniversitesi, Fen Edebiyat Fakültesi, Biyoloji Bölümü, 34722, Kadıköy-İstanbul
}

\begin{abstract}
ÖZ
Bu çalışmanın amacı, İstanbul Boğazı'ndan toplanan ve besin olarak sıklıkla tüketilen Kara midye'lerin (Mytilus galloprovincialis) solungaç ve bağırsaklarındaki gram-negatif bakteri florasının tayin edilmesidir. Midye örnekleri İstanbul Boğazı'nda belirlenen 4 istasyondan (Haliç, Karaköy, Kadıköy, Üsküdar) elle toplanmıştır. Kara midye örneklerinin bağırsak ve solungacından 17 adet gram-negatif bakteri izole edilmiş ve türlerin identifikasyonu yapılmıştır. Daha sonra tüm koloniler morfolojilerine göre değerlendirildikten sonra tiplendirme işlemi API (Biomerieux) bakteri tanımlama sistemi kullanılarak yapılmıştır. Besin olarak sıklıkla tüketilen midyelerin organ ve dokularında patojen bakteri türlerinin bulunması ve bu bakterilerin ağır metale karşı dirençli olmaları, İstanbul Boğazı'nın ekolojik kirliliği hakkında önemli bulgular sağlamıştır.
\end{abstract}

Anahtar kelimeler: Gram-negatif bakteri florası, Mytilus galloprovincialis, Mikrobiyal deniz kirliliği

\section{The Identification of Gram-Negative Bacterial Flora of Black Mussel (Mytilus galloprovincialis)}

\begin{abstract}
The aim of this study is the identification of gram negative bacterial species in the intestine and gill tissues of the mussels (Mytilus galloprovincialis Lamarck, 1819). Mussel samples were collected from four stations (Halic, Karakoy, Kadıkoy, Uskudar) of Bosphorus. Following the evaluation of all colonies according to their morphologies, API (Biomerieux) bacterial identification system was used for typology. Seventeen gram-negative bacterial species have been isolated and identified from the intestine and gills of the mussel samples. Presence of heavy metal resistant pathogenic bacteria species into organ and tissue of the mussels which consume by people as a supplemental food, have been provided significant findings on ecological pollution of Bosphorus (İstanbul).
\end{abstract}

Keywords: Gram-negative bacterial flora, Mytilus galloprovincialis, Microbial marine pollution

\section{GİRIŞ}

Son yıllardaki kontrolsüz kentleşme ve endüstrileşme ülkemiz denizlerinin kirlenmesine sebep olmuştur. Arıtılmamış veya yetersiz arıtılarak deşarjı yapılan sular, doğrudan doğruya kıyı çevrelerini kirleten kaynaklar arasındadır. İnsan ve hayvan atıklarını içeren lağım suları, deniz kıyı sularına veya yeraltı suları içine çeşitli insan patojenlerini taşır. Lağım suyu, çok fazla sayıda bakteri, enterik virüsleri ve diğer mikroorganizmaları içerir [1,2,3]. Avrupa Birliği Komisyonu 2006 yılında aldı̆̆ kararda rekreasyonel kullanıma açık alanlarda Salmonella spp., tespitinin yapılması ve bir litre deniz suyundaki Salmonella spp., sayısının litrede sıfır olması gerektiğine karar vermiştir. Deniz sularının litresinde 7.000 koliform bakteri kritik sınır olarak kabul edilir ve eğer bu sayı 10.000 olursa alanın kullanımının yasaklanması gerekmektedir [4]. Örneğin, tarım alanlarının kanalizasyon suyu ile sulanması veya kanalizasyon sularının akarsu, göl ve denizlere boşaltılması sonucu kanalizasyon sularında bulunan hastalık yapıcı mikroorganizmalar toprağa, denizlere ve atmosfere geçerek çevre kirlenmesine yol açar. Denizlerdeki patojen mikroorganizmaların her birinin varlığını tespit etmek için 
bu mikroorganizmaların bakteriyolojik analizlerini yapmak zordur. $\mathrm{Bu}$ nedenle patojen mikroorganizmaların mevcut olup olmadığını gösteren, ekolojik şartlara toleransı fazla olan gösterge yani indikatör organizmalar kullanılmaktadır $[5,6]$. Çift kabuklular (Bivalvia), kıyı bölgelerde suyu filtre ederek beslenen canlılardır [7]. Sucul çevrenin doğal bir parçası olan midyeler, zengin organik madde içeriği ile ekonomik değere sahip olan önemli ve besleyici deniz canlılarından biridir. Araştırmada kullanılan midye türü olan Mytilus galloprovincialis denizlerde gruplar halinde kayalıklara tutunur. Türkiye'de, Doğu Akdeniz kıyıları hariç Ege Denizi, Marmara Denizi, Çanakkale ve İstanbul Boğazları ile Karadeniz'de doğal yataklarda bol miktarda bulunur. Ülkemizde 7-8 $\mathrm{cm}$ boyuna geldiği zaman avlanır ve tüketilirler. M. galloprovincialis'ler "kirlilik göstergesi" olarak kabul edilirler çünkü fekal patojenleri, bakterileri, toksin, ağır metal ve radyoaktif maddeleri bünyelerinde yoğunlaştırarak taşırlar [8]. Sesil türler oldukları için uzun süreli (kronik) etkileri iyi yansıtır ve yüksek düzeyde fekal koliform bakteriyi besin zincirine katarak halk sağlığını tehdit edebilirler. Kirli deniz ortamlarında geliştikleri zaman; kolera, tifo gibi hastalıklara ve ağrı, titreme, davranış bozukluğu, kusma vb. şikâyetlere sebep olabilirler. $\mathrm{Bu}$ çalışmanın amacı, İstanbul Boğazı'ndan toplanan ve besin olarak sıklıkla tüketilen Kara midyelerin solungaç ve bağırsaklarından izole edilen gram-negatif bakterilerin tayin edilmesidir.

\section{MATERYAL VE YÖNTEM}

\subsection{Kullanılan Besiyerlerinin Hazırlanmast}

Çalışmada kullanılan besiyerleri (Nutrient Agar, Nutrient Broth, MacConkey (MAC) Agar) (MERCK) kullanma talimatına uygun şekilde hazırlanıp, otoklavda $121^{\circ} \mathrm{C}$ 'de 15 dakika steril edilmiştir [9].

\subsection{Midye Örneklerinin Hazırlanması}

Midyeler belirlenen istasyonlardaki doğal ortamlarından elle toplandıktan sonra steril deniz suyu içeren cam kaplarda laboratuvara getirilmişlerdir. Midyelerin solungaç ve bağırsağından alınan doku parçaları, önceden hazırlanan $\% 3,5$ tuz içeren steril $1 \mathrm{ml}$ deniz suyu ile ependorf tüpleri içinde cam boncuklar yardımıyla dismembranatörde parçalanmış ve homojenize edilmiştir. Ependorf tüplerinden alınan 0,1 ml homojenat, Drigalski Spatülü ile $10 \mathrm{~cm}$ çapındaki steril Petri kaplarında bulunan MacConcey Agar'a yayma plak yöntemi ile ekilmiş̧ir. Daha sonra Petri kapları inkübatöre konularak $37^{\circ} \mathrm{C}$ 'de 24 saat inkübasyona bırakılmıştır [9]. İnkübasyon sonucu üreyen kolonilerden morfolojik özelliklerine göre (renk, büyüklük, kavis, oluşturduğu zon) 17 adet farklı koloni seçilmiştir. Seçilen kolonilerden alınan örnekler, öze yardımıyla 10 ml'lik tüplerdeki steril Nutrient Broth'a ekilmiş ve $37^{\circ} \mathrm{C}$ 'de 24 saat inkübasyona bırakılmıştır [9]. Tüm koloniler morfolojilerine göre değerlendirildikten sonra tiplendirme işlemi API (Biomerieux) bakteri tanımlama sistemi kullanılarak yapılmıştır.

\section{BULGULAR}

İstanbul Boğazı'nda belirlenen dört istasyondan toplanan midye örneklerinin solungaç ve bağırsaklarından izole edilen bakterilerin tanımlanması sonucunda 17 adet farklı gram-negatif bakteri türü tespit edilmiştir (Tablo 1).

Tablo 1. İstanbul Boğazı'nda dört istasyondan toplanan Mytilus galloprovincialis'in solungaç ve bağırsaklarından izole edilen ve tanımlanan gram-negatif bakteri türleri.

\begin{tabular}{lll}
\hline Gram-negatif Bakteri Türleri & İstasyon & Organ \\
\hline Acinetobacter haemolyticus & Kadıköy & Bağırsak \\
Actinobacillus ureae & Üsküdar & Bağırsak \\
Aeromonas salmonicida & Haliç & Bağırsak \\
Bordetella trematum & Karaköy & Solungaç \\
Budvicia aquatica & Karaköy & Solungaç \\
Escherichia coli & Haliç & Bağırsak \\
Francisella tularensis & Üsküdar & Solungaç \\
Moraxella osloensis & Üsküdar & Bağırsak \\
Pantoea agglomerans & Kadıköy & Bağırsak \\
Pantoea spp., & Karaköy & Solungaç \\
Pasteurella pneumotropica & Haliç & Solungaç \\
Pseudomonas luteola & Kadıköy & Bağırsak \\
Pseudomonas stutzeri & Karaköy & Solungaç \\
Shigella group & Haliç & Solungaç \\
Sphingobacterium thalpophilum & Üsküdar & Bağırsak \\
Sphingomonas paucimobilis & Haliç & Solungaç \\
Yersinia pestis & Kadıköy & Bağırsak \\
\hline
\end{tabular}

$\mathrm{Bu}$ çalışmada, İstanbul Boğazı'ndan toplanan midyelerin solungaç ve bağırsaklarının evsel ve patojen bakterilerce zengin bir floraya sahip olduğu gözlenmiştir. Gözlemlerimiz sonucunda İstanbul Boğazı'nın ciddi şekilde fekal kirliliğe maruz kaldığını söyleyebiliriz. Çünkü normal şartlar altında midye, istakoz, karides gibi deniz canlılarında 
koliform ve fekal koliform bakteri bulunmaz. Balıklarda olduğu gibi, tatlı su istakozu, karides ve midyede bulunan bakteriyel flora çevre şartları ile yakından ilgilidir. $\mathrm{Bu}$ grup mikroorganizmaların yeni avlanmış ürünlerde yüksek sayılarda bulunması suların bu patojenler tarafindan kontamine edildiğinin göstergesidir.

\section{TARTIŞMA VE SONUÇ}

Mikroorganizmalarla olan deniz kirliliği, patojen, potansiyel patojen ve normal habitatları deniz ortamı olmayan karasal mikroorganizmalardan kaynaklanır [10]. Su ve atık sulardaki patojen bakteriler genellikle fekal orijinlidir. Belediyelerin atık sularında farmakolojik atıklar, ağır metaller, amonyum, endokrin bozucu maddeler ve mikroorganizmalar bulunur [1]. Atık sularda, özellikle dışkıda bulunan patojen bakteriler fekal kontaminasyonun esas kaynağıdır ve potansiyel sağlık risklerini oluştururlar. Deniz ve göl sularının aşırı miktarda evsel ve endüstriyel kökenli atık mikroorganizmalar ile kirlenmesi pek çok epidemiyolojik riski de beraberinde getirmektedir. Atık suların deşarj yeri olan denizler, bu bakterilerin alıcı ortamı konumundadır. Ayrıca deniz suyunda birçok enterik olmayan patojenlerde mevcuttur. Bunlar arasinda Legionella, Mycobacterium gibi bakteriler ve suda mevcut olan çeşitli firsatçı patojenler görülebilir. $\mathrm{Bu}$ bakterilerde potansiyel hastalık risklerini oluştururlar [11,12]. Donia ve arkadaşları (2012) deniz suyu kirliliğini test etmek amaciyla midye örneklerini kirli olduğunu düşündükleri bir bölgeye yerleştirmişlerdir. Moleküler testlerin yardımıyla midyelerdeki faj ve enterik virüslerin identifikasyonu yapılmıştır. Araştırmanın sonucuna göre midyelerin \%52.4'ünde en az bir enterik virüs, \%17'sinde Hepatit A virüsü (HAV), \% 8.1'inde Hepatit E virüsü (HEV) ve \% 5.4'ünde ise norovirüsler (NoV) tespit edilmiştir. Araştırmacılara göre, Mytilus galloprovincialis türü midyeler viral deniz kirliliğinin tespit edilmesinde de uygun birer biyomonitör organizmalardır [2]. Potansiyel patojenler ve normal habitatta bulunan diğer karasal mikroorganizmalar denizlerde yaşamazlar. Fakat arıtımı yapılmamış atık suların doğrudan doğruya kıyı zonlarına deşarjlarının yapılması ile denizlere erişirler $[10,13]$. Çift kabuklu yumuşakçalar besinlerden kaynaklanan hastalıklarda çok önemli bir yere sahiptirler. Ticari olarak yetiştirilen ve doğal yataklardan elde edilen $M$. edulis türü midyelerde mikrobiyal kalitenin incelendiği bir araştırmada özellikle rihtım civarından elde edilen örneklerde Escherichia coli kontaminasyonu bildirilmiştir [14]. Lhafi ve arkadaşları tarafindan 2007 yılında yapılan bir araştırmada, Almanya'nın Wadden Denizi'nden mevsimsel olarak 90 adet M. edulis toplamış ve yapılan bakteriyolojik analizler sonucunda örneklerin \%74'ünde olası insan patojenleri olan E. coli, Salmonella spp., ve Vibrio spp., tespit edilmiştir. Örneklerin toplandığ1 Wadden Denizi, gel-git zonu 2009 yllından itibaren UNESCO’nun Dünya Miras Listesi'ne alınmıştır. Vibrio spp., deniz ortamında sıklıkla bulunabilen ve gastrointestinal hastalıklara neden olan bir organizmadır. Yumuşakçalardan izole edilebildikleri de bazı araştırmalarda gösterilmiştir. Örneğin Vibrio vulnificus salgınlara neden olmamalarına karşın 50-60'1 ölümle sonuçlanan çok şiddetli sendromlar oluştururlar. Bu nedenle viral kaynaklı patojenler yüksek mortaliteye sebep olan organizmalardandır. İstiridye ve midyeler bu organizmaların deposu olarak da görülebilirler ve özellikle az pişmiş veya çiğ tüketildikleri zaman ciddi enfeksiyonlara sebep olurlar. Hepatit A virüsü (HAV) az pişmiş istiridyelerin yenilmesiyle bulaşabilir. Norovirüs (NoV), Dünya çapındaki en tehlikeli gastroenterit salgınlarına neden olan bir organizmadır. Hepatit E virüsü (HEV) ise suların fekal kontaminasyonu sonucu insanlara bulaşır ve genellikle kirli suların içilmesi veya bu sularla yıkanan çiğ besinlerin tüketilmesi ile ciddi enfeksiyonlara neden olur. Vibrio türleri deniz ve haliçlerde çok yaygın olarak bulunurlar [3]. İtalya'da yapılan bir araştırmada balık marketlerinden satın alınan Mytilus galloprovincialis türü midyelerde Vibrio parahaemolyticus, Vibrio vulnificus, Salmonella spp., fekal koliform bakteriler ve Escherichia coli belirlenmiştir. Toplanan 600 midye örneğinin mikrobiyal analizi sonucunda \% 7.83'ünde $V$. parahaemolyticus, \% 2.83 'ünde $V$. vulnificus, \% 0.16'sinda Salmonella spp., \% 4.46'sinda fekal koliform bakteriler ve \% 3.5'inde E.coli tespit edilmiştir [15]. Deniz suyunda bulunması mümkün bağırsak kökenli mikroorganizmaların en önemlileri ise E. coli, Streptococcus faecalis, Clostridium perfingens ve Salmonella, V. comma gibi olası bağırsak patojenleridir. $\mathrm{Bu}$ mikroorganizmalar fekal kontaminasyon sonucu suda bulunurlar ve içme suları için de büyük tehlike arz ederler. Buna ekolarakhayvanlar, özellikledemartılar, sindirimkanalı patojenlerinin taşıyıcıları olabileceklerinden kıyısal suların mikrobiyal kontaminasyonunda önemli ölçüde rol oynarlar. Deniz suyu çevresinin mikrobiyolojik kontaminasyonu fekal indikatör bakterilerin varlığ ile belirlenir [15]. Bazı uluslararası protokollerde olduğu gibi; ülkemizde de su mikrobiyolojisi kalite standardı parametreleri total ve fekal koliform bakterilerdir. Potansiyel patojen olan fekal koliform bakterilerin belirlenen standartlar üzerinde olması, suyun enfeksiyon yayması olarak kabul edilir. Midyeler bulundukları ortamda suyu sürekli filtre ederler. Bu nedenle kirli sularda büyüyen midyelerde bakteri ve enterik virüsler 
gibi patojenler siklıkla bulunur. Suyla beraber filtre edilen bu patojenler kabuklu türlerin bünyelerinde su kolonunda yaşayabildiklerinden birkaç gün daha fazla yaşayabilirler. $\mathrm{Bu}$ patojenlerce kontamine edilmiş kabukluların çiğ veya az pişmiş halde tüketilmeleri sonucunda da çok önemli gastrointestinal enfeksiyonlar görülür [2]. Midyelerin organlarındaki bakteriyel populasyon çeşitliliği halk sağlığı ve sucul fauna açısından risk oluşturmaktadır. Bu çalışma, İstanbul Boğazı'ndaki ekolojik problemleri araştıracak çalışmalara ve kontamine olmuş atık sulardaki bakterilerin ekolojik rollerinin aydınlatılmasında çevre kirliliğinin bugün geldiği durum ve doğal ortam kirliliğinin canlı hayatındaki rolü açısından katkı sağlamayı amaçlamaktadır. Sonuç olarak, Kara midyelerin (M. galloprovincialis) solungaç ve bağırsaklarından 17 adet hastalık yapıcı (patojen) gram-negatif bakteri izole edilmiştir. Bu çalışma, İstanbul Boğazı'nda ekolojik problemleri ve mikrobiyal çevre kirliliğinin bugün geldiği durumu irdelemektedir. Patojen mikroorganizmalarla kontamine olmuş kıyısal alanlarda yaşayan diğer canlı türleri üzerine ekolojik hasarların sıklıkla kontrol edilmesi ve belirlenmesi de gerekmektedir.

\section{TEŞEKKÜR}

$\mathrm{Bu}$ çalışma Marmara Üniversitesi, Bilimsel Araştırma Projeleri Komisyonu (BAPKO) tarafindan FEN-CYLP-040310-0043 no'lu proje olarak desteklenmiştir.

\section{KAYNAKLAR}

[1] Bianchi, V.A., Castro, J.M., Rocchetta, I., \& Bieczynski, F. (2014). Health status and bioremediation capacity of wild freshwater mussels (Diplodon chilensis) exposed to sewage water pollution in a glacial Patagonian Lake. Fish\&Shelfish Immunology, 37, 267-277. doi:org/10.1016/j.fsi.2014.02.013.

[2] Donia, D., Dell'Amico, M.C., Petrinca, A.R., Martinucci, I., Mazzei, M., Tolari, F., \& Divizia, M. (2012). Presence of hepatitis E RNA in mussels used as bio-monitors of viral marine pollution. Journal of Virological Methods, 186,198202. doi:http://dx.doi.org/10.1016/j.jviromet.2012.06.007.

[3] Lhafi, S.K., \& Kühne, M. (2007). Occurence of Vibrio spp., in blue mussels (M. edulis) from the German Wadden Sea. International Journal of Food Microbiology, 116, 297-300. doi:10.1016/j.ijfoodmicro.2007.01.007.
[4] Anonim. (2006). Su Kirliliği Kontrolü Yönetmeliği. T.C. Resmi Gazete No.19919, Ankara.

[5] Feldhusen, F. (2000). The role of seafood in bacterial foodborn disease. Microbes and Infection, 2: 1651-1660. doi:10.1016/S1286-4579(00)01321-6.

[6] Collado, L., Jara, R., Vasquez, N., \& Telsaint, C. (2014). Antimicrobial resistance and virulence genes of Arcobacter isolaters recovered from ediple bivalve molluscs. Food Control, 46,508-512.

[7] Stabili, L., Immacolata-Acquaviva, M.I., \& Cavallo, R.A. (2004). Mytilus galloprovincialis filter feeding on the bacterial community in a Mediterranean coastal area (Northern Ionian Sea, Italy). Water Research, 39(2-3), 469477. doi: 10.1016/j.watres.2004.10.010.

[8] Kristan, U., Kanduc, T., Osterc, O.,Slejkovec, Z., Ramsak, A., \& Stibilj, V. (2014). Assessment of pollution level using Mytilus galloprovincialis as a bioindicator species: The case of the Gulf of Trieste. Marine Pollution Bulletin, 89,455-463.

[9] Merck Microbiology Manual. (2005). Merck KGaA, Darmstadt, Germany.

[10] Efstratiou, M.A. (2001). Managing coastal bathing water quality: the contribution of microbiology and epidemiology. Marine Pollution Bulletin, 42(6), 425-432. doi:10.1016/ S0025-326X(00)00225-3.

[11] Ji, C., Wu,H., Wei, L., Zhao, J., Wang, Q., \& Lu, H. (2013). Responses of Mytilus galloprovincialis to bacterial challenges by metabolomics and proteomics. Fish and Shellfish Immunology, 35,489-498.

[12] Toze, R. (1999). PCR and the detection of microbial pathogens in water and wastewater. Water Research, 33 (17), 3545-3556. doi: 10.1016/S0043-1354(99)00071-8.

[13] Akdoğan, Z., Küçükdoğan, A., \& Güven, B. (2015). Yayılı kirleticilerin havzalardaki taşınım süreçleri: Antibiyotikler, ağır metaller ve besi maddeleri üzerine modelleme yaklaşımları. Marmara Fen Bilimleri Dergisi, 1, 21-31.

[14] De Witte, B., Devriese, L., Bekaert, K., Hoffman, S. Vandermeersch, G., Cooreman, K., \& Robbens, J. (2014). Quality assessment of the Blue mussel (Mytilus edulis): Comparison between commercial and the wild types. Marine Pollution Bulletin, 85,146-155. doi:http://dx.doi. org/10.1016/j.marpolbul.2014.06.006.

[15] Normanno, G., Parisi, A., Addante, N., Quaglia, N.C., Dambrosio, A., Montagna, C., \& Chiocco, D. (2006). Vibrio parahaemolyticus, Vibrio vulnificus and microorganisms of fecal origin in mussels (Mytilus galloprovincialis) sold in the Puglia Region (Italy). International Journal of Food Microbiology, 106,219-222. doi:10.1016/j. ijfoodmicro.2005.05.020. 